\title{
FROM THE LINER VULCANIA \\ TO THE MARTIN MEMORIAL LECTURES: PAUL OSKAR KRISTELLER’s FIRST FIFTEEN YEARS IN AMERICA*
}

\author{
JOHN MONFASANI \\ UNIVERSITY AT ALBANY - SUNY
}

In his Life of Learning lecture at the annual meeting in 1990 of the American Council of Learned Societies, Paul Oskar Kristeller compared his life to the horseman who looked back after having climbed up on the shore of Lake Constance only to see dissolving behind him the lake ice that he himself had just crossed. ${ }^{1}$ Well could he make such an analogy. In the early 1930s Kristeller left Nazi Germany for Italy, although up to that point in time he had been preparing for an academic career in Germany. Then, on 23 February 1938 he landed in New York on the liner Vulcania having left Fascist Italy eleven days earlier. ${ }^{2} \mathrm{He}$

* This is the talk I delivered at the workshop The Renaissance in Exile: German Renaissance Scholars in Europe and North America (1930-2000) at the Lichtenberg-Kolleg, Göttingen, on 16 May 2019.

1 He was alluding to, though not quite accurately, the ballad Der Reiter über den Bodensee of Gustav Schwab (1792-1850), which seems to have been read by every educated German speaker at school. See WolfGANG MIEDER, Aphorismen, Sprichwörter, Zitate von Goethe und Schiller bis Victor Klemperer, Peter Lang, Bern 2000 (Sprichwörterforschung, 22), p. 55-93. For instance, the tale is alluded to by the writer and Soviet spy G. F. ('GustI') STRIDSBERG (1892-1978) in her memoir, My Five Lives: An Autobiography, trans. ARNOLD J. Pomerans, Heinemann, London 1963, p. 263; by the Auschwitz survivor RUTH KLUGER in her Still Alive: A Holocaust Girlhood Remembered, Feminist Press, European Classics Edition, New York 2012 (first edition 2001), p. 184-185; by the psychologist KURT KOFFKA (1886-1941) in his Principles of Gestalt Psychology, Harcourt Brace, New York 1935, p. 27-28; and by Kristeller's fellow refugee and student of Heidegger, HANNAH ARENDT (1906-1975), in her The Promise of Politics, intr. and ed. Jerome KoHn, Schocken Books, New York 2006, p. 193.

2 In his Reminiscences (Columbia University, Oral History Archives), Kristeller wrongly claims that he sailed on the Vulcania's sister ship, the Saturnia: (p. 360) «Then I departed from Naples on February $12^{\text {th }} 1939$ on the Italian steamboat Saturnia. The boat trip lasted 11 days, with landings in Algiers - where I did go ashore and saw the Casbah - and in Gibraltar and the Azores ». Kristeller's boat ticket on the Vulcania survives among his papers in Columbia University's Rare Book and Manuscript Library, Paul Oskar Kristeller Papers (henceforth POKP), Box 77, folder 6. We also
\end{abstract}


genuinely had wanted to become an Italian citizen and up to less than a year before had every hope of continuing his scholarly career in Italy. ${ }^{3}$ What he could not know at the time while enduring both exiles was that he was escaping the catastrophic effects of the impending Holocaust and World War II in his country of birth and in his second, as he then thought, homeland for the safe, ${ }^{4}$ but to him quite foreign, harbor of America, where he would spend the remaining sixty years of his life. ${ }^{5}$

have the manifest of 'alien' passengers on the Vulcania for the voyage dated the day he boarded the ship in Naples, 12 February 1939; Kristeller is no. 21 in the list, where his family name at birth, Gräfenberg, is also given (I downloaded the manifest from Ancestry.com, NYT715 6287-0410). HANS Peter OBERMAYER, Deutsche Altertumswissenschaftler im amerikanischen Exil: Eine Rekonstruktion, De Gruyter, Berlin 2014, p. 492, quotes Kristeller's letter to his parents on 29 January 1939 telling them that he was sailing on the Vulcania. Cf. the voyage on the Vulcania later that same year, likewise caused by Mussolini's racial laws, of the future Reformation scholar and friend of Kristeller's, the then seven-year old JoHn TEDEsCHI, in his (with ANNE C. TeDESCHI) Italian Jews Under Fascism, 1938-1945, Parallel Press - University of Wisconsin - Madison Libraries, Madison, WI, 2015, p. 1-2. Tedeschi also points out Kristeller's error in ID., « Paul Oskar Kristeller: The Italian Years, 1933-1939 », in DeAnNa ShemeK, Michael Wyatt (eds.), Writings Relations. American Scholars in Italian Archives. Essays for Franca Petrucci Nardelli and Armando Petrucci, Leo S. Olschki, Firenze 2008 (Biblioteca dell'Archivum Romanicum. Serie 1. Storia, letteratura, paleografia, 347), p. 191-217, at p. 214 , fn. 79.

3 On the effort and expectation of gaining Italian citizenship for Kristeller, see TEDESCHI, « Kristeller: The Italian Years ", 210-204; OBERMAYER, Deutsche Altertumswissenschaftler, p. 438-442, 451-459. There is only a brief reference in KRISTELLER, Reminiscences, p. 274-275. However, a letter he wrote Cardinal Giovanni Mercati on 29 March 1937 shows that he put considerable thought into the attempt: "Ora i miei amici mi hanno consigliato di far domanda per ottenere la cittadinanza italiana. È questa una decisione molto grave, perché non si dimentica così facilmente il proprio paese nativo [...] Ma dopo che il governo tedesco mi ha tolto quasi tutto ciò che l'arbitrio degli uomini può togliere e dopo che in parecchi anni di soggiorno ho approfondito sempre di più $i$ miei rapporti personali ed intellettuali coll'Italia, ho preso quella decisione [...] mi trovo perfino nella situazione paradossale che, essendo suddito tedesco [...] non posso andare in Germania per salutare i miei genitori, mentre come suddito straniero lo potrei fare senz'altro » (PAolo Vian, «L'opera del card. Giovanni Mercati per gli studiosi perseguitati per motivi razziali. L'appello alle Università Americane [15 dicembre 1938]», in Miscellanea Bibliothecae Apostolicae Vaticanae, 9 [= Studi e Testi, 409], Biblioteca Apostolica Vaticana, Città del Vaticano 2002, p. 427-500, at p. 473).

4 In an interview in Sant'Anna News. Newsletter dell'Associazione Ex-Allievi Scuola Superiore S. Anna-Pisa, 4 (Dec. 1994), p. 18-20, on p. 18, he declared: «Sentivo l'Italia come la mia seconda patria ». See also JoHn MonfASAnI, "Italy in the Career of Paul Oskar Kristeller », in ANDREA ALBRECHT, LUTZ DANNEBERG, Simone De Angelis (eds.), Die akademische Achse Berlin-Rom? Der wissenschaftlich-kulturelle Austausch zwischen Italien und Deutschland 1920 bis 1945, De Gruyter Oldenbourg, Berlin 2017, p. 83103, p. 83, fn. 1.

5 Kristeller would always commemorate the day of his arrival. For instance, in a letter of 20 February 1964 to Roland and Ruth Bainton, Kristeller began: « On February 23, it will be exactly 25 years since I first came to this country. On this occasion, I should like to thank you for all your help and kindness with which you managed to bring me over, out of a most difficult situation » (POKP, Box 3, folder 2; photocopy of the original in the Roland Bainton Papers, Yale Divinity School). On Bainton's pivotal role in rescuing Kristeller from Italy in 1939, see fn. 7 below. 
An anecdote told me many years ago suggests how traumatized Kristeller was by his expulsion from Italy. ${ }^{6}$ When the Vulcania docked in New York, one of the sponsors of Kristeller's non-quota visa, Hermann Weigand, and his wife were there to greet him and take him by car to their home outside of New Haven, Connecticut. ${ }^{7}$ During the ride Kristeller remained silent. Upon entering the Weigand's home he saw their piano, headed straight for it, and played for an hour or more. Then, and only then, could he open up and speak freely with his hosts. A talented pianist who once toyed with the idea of turning professional and who often played for his teacher Marin Heidegger and his family in their home, ${ }^{8}$ Kristeller practiced daily all through his school years in Germany and continued to do so in Italy, using the piano of the Scuola Normale Superiore in Pisa, where he taught and lived. ${ }^{9}$ Only in 1945, right after World War II, did he stop, when the press of work made him decide that he no longer had the time for this obviously deeply satisfying exercise. ${ }^{10}$ On the day of his arrival in America in February 1939,

6 This was told to me by the classicist Berthe Marti at dinner one evening at the American Academy in Rome in the fall of 1969.

7 See KRISTELleR, Reminiscences, p. 362-363. On the background to the efforts of Weigand, Roland Bainton, and others to bring Kristeller to America, see OBERMAYER, Deutsche Altertumswissenschaftler, p. 461-501; and JoHN TEDESCHI, The Correspondence of Roland H. Bainton and Delio Cantimori, 1932-1966: An Enduring Transatlantic Friendship between Two Historians of Religious Toleration, Leo S. Olschki, Firenze 2002 (Studi e Testi per la Storia della Tolleranza in Europa nei secoli XVI-XVIII, 6), p. 90-105.

8 See KRISTELleR, Reminiscences, p. 66: «I must say that in my younger years music played such an important role in my life that there were moments when I was not doing well in my studies, that I played with the idea of becoming a professional musician. But it didn't come to that, and I don't think I regret it. I think I made the right choice in the long run. But it was a great temptation ». For Kristeller's playing for Heidegger, see ibid., p. 62, 109, 165; and ID., with MARGARET L. KING, «Iter Kristellerianum: The European Journey (1905-1939) », Renaissance Quarterly, 47 (1994), p. 907-929, at p. 917. When Kristeller and Heidegger resumed contact in 1970s, they both mentioned this piano playing at Heidegger's house; see John MonfasanI, « Paul Oskar Kristeller and His German Professors ", forthcoming in Parola del Passato. Rivista di studi antichi, at fn. 55 and 56.

9 See Karl-Eugen Gass, Diario Pisano, 1937-1938, trans. Giovanna Cermelli, annot. Malis Ingenmey, intr. Marianello Marianelli, Nistri Lischi, Pisa 1989, p. 21-22. See also ibid., p. 108-109, where Gass, who died on the Western Front in 1944 after being been called into the German military, describes a long philosophical discussion he had with Kristeller on an evening walk in Pisa. In a letter of 1989, Kristeller wrote Marianelli: «Serbo un ricordo vivo del Gass giovane studioso serio, ingegnoso e simpatico che ho conosciuto alla Scuola Normale nel 1937 e 1938 e con cui ho avuto molte conversazioni interessanti » (p. xxIx, fn. 36). The original German publication, KARL-EUGEN GASS, Pisaner Tagebuch. Aufzeichnungen / Briefe aus dem Nachlass eines Frühvollendeten, ed. PAUL EGON HÜBNER, Verlag Lambert Schneider, Heidelberg - Darmstadt 1961, does not identify Kristeller as the person whom Gass refers to as " $\mathrm{Ch}$ ». In the German text the passages cited above are on p. 22-23 and 92-93.

10 KRISTELleR, Reminiscences, p. 63: « but then after the end of the war I got involved in so many time consuming research projects that I could never any longer spare the time to practice. So my ability declined, and finally I got so tired of my reduced ability that I dropped it altogether ». In a letter of 8 December 1995 to W. Cameron McEwan (POKP, Box 35, folder 6), Kristeller related that 
however, playing the piano helped him to settle his nerves and regain his composure.

Little could Kristeller have realized that day that he was about to embark on the most creative and productive fifteen years of his life. ${ }^{11}$ Indeed, one could argue that the remaining forty-five years of his life were nothing more than the fulfillment of the scholarly projects he had commenced in those first fifteen years, 1939-1954, as the greatness of his scholarship became ever more recognized and influential.

Some of what Kristeller first accomplished in America was a consequence of his Italian years. He completed in Italy his still standard monograph on the philosophy of Marsilio Ficino, ${ }^{12}$ but saw it published for the first time in America in an English translation in $1943 .{ }^{13}$ Furthermore, he had conceived in his last years in Italy the project that would become the Iter Italicum, but without having a real sense of its vastness or knowing what to call it. ${ }^{14}$ In June 1945, Leonardo Olschki, another refugee European exile, ${ }^{15}$ writing from Berkeley, California, sent Kristeller a postcard to alert him that Fritz Saxl of the Warburg Institute was now in New York. Kristeller did meet with Saxl in New York and that meeting marked the formal start of Iter Italicum. ${ }^{16}$ As Kristeller memoralized in the preface to

« My activity as a pianist stopped in 1945 when I was no longer able to practice two hours each day ». He had already said the same in a letter of 25 April 1994 to McEwan.

11 Rightly Giuseppe VeluI, « Paul Oskar Kristeller: una vita per gli studi », in Gli studi umanistici e l'opera di Paul Oskar Kristeller, Milano, 18 maggio 2000, Istituto Lombardo di Scienze e Lettere, Milano 2001, p. 7-15, at p. 7, remarked: «È infatti straordinaria la quantità di lavoro svolto da Kristeller nei suoi primi dieci-quindici anni americani ».

12 It is worth noting that the doctorate Kristeller received from the University of Pisa in 1937 had nothing to do with his work on Ficino; see KRISTELlER, Reminiscences, p. 273: «Actually in 1937 I received a diploma from the University of Pisa, and I did not have to pass any examinations, and I did not have to submit any new dissertation, but they gave a degree as a kind of Italian validation of my German degree [...] signed by King Vittorio Emanuele II also as Emperor of Ethiopia ».

13 For the gestation and history of this study of Ficino see JoHn MONFASANI, "Italy in the Career ", p. 85-87; KRISTELLER, Reminiscences, p. 287-288, 517-520; and the preface to the definitive edition: Paul Oskar Kristeller, Il pensiero filosofico di Marsilio Ficino. Edizione riveduta con bibliografia aggiornata, Casa Editrice Le Lettere, Firenze 1988, p. XIX-XX.

14 MoNFASANI, «Italy in the Career », p. 88-90.

15 See ANKE DöRNER, La vita spezzata. Leonardo Olschki: ein jüdischer Romanist zwischen Integration und Emigration, Stauffenburg Verlag, Tübingen 2005 (Romanica et Comparatistica, 38).

16 In POKP, Box 50, folder 5; the postcard is dated 14 June 1945. In the Reminiscences, p. 558-562, Kristeller talks about his meeting with Saxl and the start of the project, but misdates the meeting to the spring of 1945. There is an extensive correspondence between Kristeller and Saxl in POKP and in the Archive of the Warburg Institute, London, that should be published. Kristeller first contacted Saxl with a two-page handwritten letter of 11 March 1937 introducing himself by rehearsing his scholarly record and proposing "a sort of bibliographic Handbuch » of the manuscript and bibliographic material he had collected on humanism. Saxl responded on 16 March, saying that such a «lange formelle Einführung » was really unnecessary and expressing interest in Kristeller's Handbuch. The conversation changed in September 1937 to how to rescue 
volume I of the Iter: « When I met the late Fritz Saxl in 1945, I told him of my material, and it was thanks to his foresight and interest that the plan of the present work emerged and took pretty much its final shape $»{ }^{17}$ So the Iter as a publication originated in New York in 1945. Finally, in 1944, he published in the new American journal Traditio a ground-breaking article on the scholastic background of Marsilio Ficino based on texts he had discovered in Italy shortly before being forced to leave in $1939 .{ }^{18}$ Thus, by leveraging his prior Italian scholarship, Kristeller had, by the mid-1940s, successfully transformed himself into a major Anglophone scholar.

But the relationship also worked in the other direction. The challenges and stimuli of his new American environment also altered Kristeller and his scholarship in decisively important ways. I count at least five.

First, Kristeller came to America as an expert on Renaissance Platonism. His study of Marsilio Ficino first took shape at Freiburg under Martin Heidegger and was completed at the Scuola Normale Superiore in Pisa. This study of Marsilio Ficino was itself a logical progression from Kristeller's first major publication, a study of Plotinus, the founder of Neoplatonism, in 1928. Indeed, Kristeller escaped Fascist Italy in 1939 precisely because he was an expert on Neoplatonism, having been given a non-quota visa to come to America to teach a seminar on Plotinus at Yale University. ${ }^{19}$ But once arrived in Columbia University from Yale in the summer of 1939, Kristeller met up with John Herman Randall, who was enthusiastically studying the Aristotelianism of the University of Padua in the sixteenth century, and then Ernest Moody, who would soon become famous for his book on the logic of William of Ockham. ${ }^{20}$ Kristeller had first seriously

Kristeller after Mussolini's racial laws. Kristeller's first written response to the meeting in New York in the summer of 1945 was a letter of 27 August 1945 expressing satisfaction at finally meeting Saxl and saying he would like « to take advantage of your kind offer concerning my Iter Italicum ».

17 PaUl Oskar KRISTElLeR, Iter Italicum: A Finding List of Uncatalogued or Incompletely Catalogued Humanistic Manuscripts of the Renaissance in Italian and Other Libraries, 7 vols., Warburg Institute - E. J. Brill, London - Leiden 1963-1997, vol. I, p. XI.

18 One of the editors of Traditio, Stephan Kuttner, wrote two letters to Kristeller from Washington, DC, on 13 October 1943, one a typed formal letter in English and another an informal handwritten letter in German, in the former of which he reported: "When I last saw you here in Washington, we informally discussed the possibility of your contributing an article to Traditio, vol. II (1943). At that time you told me that you had some unpublished Ficinian texts which you would like to edit [...] I wish to make clear by the present letter that the editors of Traditio should be extremely glad to have this article » (POKP, Box 32, folder 1). The article « The Scholastic Background of Marsilio Ficino. With an Edition of Unpublished Texts » appeared in Traditio, 2 (1944), p. 257-318 (= TномAS GILBHARD, Bibliographia Kristelleriana: A Bibliography of the Publications of Paul Oskar Kristeller, 1929-1999, Edizioni di Storia e Letteratura, Roma 2006, p. 12, no. 69).

19 See fn. 7 above.

20 See John Monfasani, «Paul Oskar Kristeller and Philosophy », Bulletin de philosophie médiévale, 57 (2015), p. 383-413, at p. 385-386; and ID., « Italy in the Career », p. 92-94. 
encountered medieval scholasticism when he briefly was in limbo between the time he had been expelled from the Scuola Normale in the summer of 1938 and was able to leave for America in February 1939. He fortunately had been hired by the Vatican to help with the cataloging of scholastic manuscripts and was guided in this new intellectual field by Auguste Pelzer. ${ }^{21}$ By the early 1940s in America Kristeller had become a passionate student of Italian scholasticism and of the greatest of the Italian scholastics, Pietro Pomponazzi. So committed had Kristeller become to these new endeavors that he set out to write an intellectual history of the Italian universities, all the while living without a secure job, producing an amazing number of studies, talks, and reviews, and working frantically to get his parents out of Nazi Germany. ${ }^{22}$ In the event, Kristeller never wrote the promised book on the Italian universities, the only major project in his

See MonfASANI, « Italy in the Career », p. 91

22 Kristeller first tried to extract his parents from Germany via Italy; see TEDESCHI, « Kristeller: The Italian Years ", p. 214-215, who proves that in 1940 Kristeller's Italian patron, Giovanni Gentile, successfully got Mussolini to grant Kristeller's parents an exceptional visa, but by the time they tried to take advantage of the privilege in June 1940, it had been withdrawn. Tedeschi drew his documentation from the Archivio Centrale dello Stato, Rome. POKP Box 65, folder 8, contains a letter of 1 May 1940 from the Ministro degli Affari Esteri to Gentile telling him that the order for the desired disposizioni had been forwarded that very day to the Consolato Generale in Berlin. Tedeschi, p. 215, quotes Bainton as saying in December 1940 after these events that « [Kristeller] is still too distraught by efforts to help friends and relatives to settle down again to any major production ». The same folder contains a letter of Julius Kurz to Kristeller of 26 March 1940 recounting how he had visited his parents in Berlin and recommending that visas be sought from Brasil, Mexico, or Panama. Kristeller investigated obtaining a visa from other countries, including Sweden, but decided on Cuba as the most feasible. The same folder contains the documentation. He paid $\$ 1,500$ for the visa and $\$ 800$ to a travel agent to bring his parents to Cuba (the folder contains a typed list in five columns of seven friends who pledged $\$ 750$ in total towards these costs; four of whom actually made the pledged loans and, as recorded in the final column, were repaid by Kristeller). But on 9 June 1942 Ella Dekuzcynski in a notarized memorandum reported that she talked to Kristeller's father Heinrich in Berlin on 15 May, who told her that the Cuban visa application had been rejected (see Appendix 1). The folder contains several letters showing Kristeller attempting in vain to recover the money he had spent on the rejected visa. But the worst news only arrived in 1945 with a letter of 8 June from the U. S. Department of Justice that the visa preference status for his parents has been revoked because they had died in Therisienstadt in 1943. A letter from the American Red Cross of 23 July confirmed that they had died. In the Gedenkbuch. Opfer der Verfolgung der Juden unter der nationalsozialistischen Gewaltherrschaft in Deutschland 1933-1945, 2 vols., Frankfurt a. M., 1986, vol. I, p. 784, Heinrich Kristeller is reported as having died on 3 December 1942, and Alice Kristeller, née Magnus, in March 1943. Theresienstädter Gedenkbuch. Kie Opfer der Judentransporte aus Deutschland nach Theresienstadt, 1942-1945, Institut Theresienstädter Initiative im Verlag Academia, Prague 2000, p. 114, agrees on Heinrich date of death and fixes Alice's as 19 March 1943. Both are also recorded in Gedenkbuch Berlins des jüdischen Opher des Nationalsozialismus, Edition Hentrich, Berlin 1995, p. 882. See alsoTEDESCHI, «Kristeller: The Italian Years», p. 216. 
very long life that he failed to see through to the end. ${ }^{23}$ But his research in preparation for the never completed monograph had several consequential results. He published four articles on Pompanazzi, including an edition of two previously unknown texts of Pomponazzi. ${ }^{24}$ His publication of original studies on Italian Renaissance scholasticism, Aristotelianism, and universities amounted to something like twenty-two separate items (not counting reprints and translations), including several ground-breaking studies on the medical school of Salerno and Petrarch's relationship with scholasticism as well as articles on the structure and curriculum of Italian universities and on those much debated designations, Italian Averroism and Alexandrism. ${ }^{25}$ Thus, justly and with authority he could include a chapter on Pomponazzi and Italian universities in his highly successful manual, Eight Philosophers of the Italian Renaissance, not to speak of his classic study of Thomism in the Italian Renaissance. ${ }^{26}$ Not by chance

23 In the end the projected resulted in PAUL F. GRENDLER, The Universities of the Italian Renaissance, Johns Hopkins University Press, Baltimore 2002. For the convoluted history of the project see ID., « Paul Oskar Kristeller on Renaissance Universities ", in JoHn Monfasani (ed.), Kristeller Reconsidered: Essays on His Life and Scholarship, Italica Press, New York 2006, p. 89-130; and ID., "Studies on the Universities of the Renaissance: An unpublished Work of Paul Oskar Kristeller ", History of Universities, 24 (2009), p. 36-68. Grendler rightly notes on p. 36 that Kristeller's research on the universities is preserved in 83 spiral notebooks (now in Box 149 of POKP rather than in Box 27 as they were found at the time of Grendler's article). He wrongly asserts, however, that Kristeller " probably began to gather information in the 1930s ». Grendler himself seems never to have made use of Kristeller's notes; and Charles Schmitt told me, although I do not recall exactly when, that neither he nor Nancy Siraisi, the other person to whom Kristeller had initially turned over the project, ever profited from the massive documentation in the notebooks because they found Kristeller's handwriting too difficult to decipher for easy consultation.

24 Kristeller's first article was a comparison of Pomponazzi and Ficino in 1944 (GILBHARD, Bibliographia, no. 68), followed by the announcement of a manuscript discovery in 1951 (ibid., no. 138), the edition of two unpublished questions of Pomponazzi in 1955 (ibid., no. 177), and a synthetic article on Pomponazzi in 1983 (ibid., no. 523).

25 In addition to the four items on Pomponazzi mentioned in the previous note, Kristeller produced six works on the school of Salerno, i. e., first an article as early as 1945 (ibid., no. 74), another in 1957 (ibid., 196), a third in 1959 (ibid., no. 209), a fourth in 1967 (ibid., no. 329), a fifth in 1976 (ibid., no. 423), and a small monograph in 1987 (ibid., no. 588). Furthermore, he had published four articles on Renaissance universities: a first article in 1953 (ibid., no. 157), another in 1956 (ibid., no. 189), a third in 1985 (ibid., no. 569), and a fourth in 1987 (ibid., no. 599). There were two work on Thomism: the classic monograph on Renaissance Thomism in 1967 (ibid., no. 335) and an article on the influence of Thomas Aquinas upon the jurist Bornio da Sala in 1987 (ibid., no. 553). And then there was a series of individual articles, some very memorable, such as on Petrarch's 'Averroists' in 1952 in (ibid., no. 149), on an Averroistic treatise to Guido Cavalcanti in 1975 (ibid., no. 175), on Paduan Averroism and Alexandrism in 1960 (ibid., no. 232), and on Renaissance Aristotelianism in 1962 (ibid., no. 258). Finally, we need to mention two early articles, one on the scholastic background of Marsilio Ficino (in 1944; ibid., no. 69) and another on an Aristotelian manuscript glossed by Francesco and Ermolao Barbaro that is a contribution to Renaissance Aristotelianism rather than scholasticism (in 1948; ibid., no. 99).

26 See the previous note. 
did he oversee a substantial number of doctoral dissertations at Columbia University on scholasticism in and outside of Italy. Indeed, about a third of the dissertations at Columbia for which he served as the first or second reader were on a scholastic author. ${ }^{27}$ So, not surprisingly, very soon after Kristeller came to America, someone who became a dear friend, Dean Lockwood, then writing a book on the fifteenth-century Italian scholastic Ugo Benzi, frequently turned to Kristeller for expert advice on the arcana of Italian scholasticism. ${ }^{28}$ However, one of the greatest effects of Kristeller's transformation into an expert on Italian scholasticism and Aristotelianism involves a seemingly very different subject, Renaissance humanism, which brings us to the second major change that Kristeller's arrival in America wrought in his thinking and scholarship.

Kristeller's most famous and most controversial assertion is his interpretation of Renaissance humanism. As he put it in what was the first formulation of his interpretation, the article "Humanism and Scholasticism in the Italian Renaissance » of 1946: «I would like to suggest that the Italian humanists on the whole were neither good nor bad philosophers, but no philosophers at all $»{ }^{29}$ Rather, as he put it in the Martin Classical Lectures of 1954, "I merely want to point out that Renaissance humanism must be understood as a characteristic phase in what may be called the rhetorical tradition in Western culture $»^{30}$ The humanists were professional practitioners of the studia humanitatis, that is to say, " a clearly defined cycle of scholarly disciplines, namely grammar, rhetoric, history, poetry, and moral philosophy $"{ }^{31}$ Several decades ago I ventured to explain how Kristeller came to his revolutionary interpretation on the basis of his unique, one might say, idiosyncratic training in Germany. ${ }^{32}$ What I said then I think still holds true, but more can be added. As is well known, Kristeller was

27 See the list of thirty-one dissertations in Monfasani, Kristeller and Philosophy, p. 386, fn. 14, ten of which involve a scholastic author.

28 See Lockwood's letters of 15 July 1939, 24 November 1939, and 22 February 1940 in POKP, Box 33, folder 12. Lockwood provides us with a humorous moment in Kristeller's education into the less formal ways of his new environment when he began a letter of 15 July 1939 to Kristeller: « Dont [sic] call me 'Prof.' any more, please. I think we know each other well enough to drop titles ».

29 The article first appeared in Byzantion, 17 (1944-1945) (recte 1946), p. 346-374 (= Gilbhard, Bibliographia, no. 73). I shall quote from the slightly revised reprint in PAUL OSKAR KRISTELLER, Renaissance Thought and Its Sources, ed. Michael Mooney, Columbia University Press, New York 1979, p. $85-105$, and in this instance, p. 91. On the date of the first publication of the article see John Monfasani, "Toward the Genesis of the Kristeller Thesis of Renaissance Humanism: Four Bibliographical Notes », Renaissance Quarterly, 53 (2000), p. 1156-1173, at p. 1156, fn. 2, reprinted as Essay XV in ID., Renaissance Humanism from the Middle Ages to Modern Times, Ashgate, Farnham 2015 (Variorum Collected Studies Series, 1057).

30 PAUl OsKar KRISTEller, The Classics and Renaissance Thought, Harvard University Press for Oberlin College, Cambridge, MA, 1955 (Martin Classical Lectures, 15), which I shall cite from the reprint in ID., Renaissance Thought and Its Sources, p. 17-81, and in this case, p. 23-24.

31 Ibid., p. 22.

32 MonfASANI, « Toward the Genesis ». See also ID., « Kristeller and His German Professors ». 
trained in the history of philosophy at Heidelberg, Marburg, and Freiburg under multiple distinguished professors, beginning with Ernest Hoffmann and ending with Martin Heidegger. It is also well known that he earned a doctorate in classical philology under the tutelage of Werner Jaeger, Edouard Norden, and others in Berlin. These dual degrees gave him a keen understanding of the rhetorical and philosophical traditions in antiquity. But what was critical for his interpretation of humanism was something less mentioned, namely, his interest in medieval history and his seminars with historians associated with the Monumenta Germaniae Historica who introduced him to the world of medieval documents and specifically to the ars dictaminis, the art of letter writing that formed the core of medieval rhetoric and the training of medieval notaries, secretaries, and their university teachers. It was the knowledge and experience gained from this historical training that led Kristeller to the insight that the Renaissance humanists were the professional successors of the medieval dictatores and therefore representatives of a phase in the rhetorical tradition of the West. The catalyst that brought all these elements of Kristeller's training together was his participation in 1942 in a panel at the annual conference of the Medieval Academy of America to discuss Richard McKeon's paper « Rhetoric in the Middle Ages ». Faced with the task of commenting on McKeon's paper, Kristeller realized that he could not disagree more with McKeon's geistesgeschichtlichte approach to the topic, totally unmoored from the practical realities of medieval document writing and professional practice. ${ }^{33}$ Two years later, in 1944, in a lecture at Connecticut College, Kristeller revealed his solution, and another two years later, in 1946, his article « Humanism and Scholasticism » came out in Byzantion. Kristeller had not only rebuked McKeon's approach to medieval rhetoric based purely on intellectual categories, but also demolished the view of those who wanted to make Renaissance humanism a philosophy or an ideology. He furthered showed those who approached Renaissance humanism as essentially a classical revival that it was in fact so much more and that the classical interests of the humanists needed to be seen in a wider cultural and societal context. What I had failed to do in my article of 2000 on the genesis of the Kristeller thesis was adequately to take into account the second element in Kristeller's title, «Humanism and Scholasticism». Because of his new found expertise on Italian universities and scholasticism Kristeller could in one stroke contrast the professional rhetoricians and professional philosophers of the Italian Renaissance and demonstrate that far from pushing aside a moribund scholasticism, humanism emerged in Italy at exactly the same time as did an enormously vibrant scholasticism and that throughout the Renaissance humanism and scholasticism competed not as two radically different

33 Monfasani, « Toward the Genesis ». 
John Monfasani

philosophies but as two rival learned cultures, i. e., a renewal of the classical competition between the rhetorical and philosophical traditions.

The Kristeller thesis has engendered considerable opposition from those who, I would contend, hold a magical and/or solipsistic view of humanism, i.e., on the one hand, - poof! - Renaissance humanism just happened without any realistic explanation of how it originated or sustained itself; and on the other, how it wonderfully espoused a worldview or attitude that a particular scholar approves and even commends to the contemporary world. ${ }^{34}$ The fact that today the only interpretation proponents of a new interpretation seek to refute or modify is Kristeller's confirms that the Kristeller thesis has swept the field.

Arrival in America wrought a third change in Kristeller. Whereas, as far as I know, he had never given a public lecture in Europe, in America he suddenly became an itinerant speaker. Apart from the courses he taught at Yale, Columbia, and New York's City College, in his first three years in America he gave at least twenty talks in locations as varied as the University of Michigan, Duke University in North Carolina, Harvard University, Brown University in Providence, Rhode Island, Connecticut College in New London, Connecticut, and multiple professional gatherings in different venues. ${ }^{35}$ Kristeller would go on to become for the rest of his career an inveterate lecturer all over America and Europe, but not until he was forced in 1939 to make public presentations in pursuit of a job and in order to establish himself in America by making contact with various learned groups did he almost overnight blossom into a highly successful and much traveled public speaker.

Kristeller's peripatetic lecturing connects to the fourth change one can see in him once he arrived in America. He very quickly developed into an extraordinary organizer of cooperative scholarly ventures. One can see indications of this talent already during his days at the Scuola Normale Superiore in Pisa, where he persuaded the director, Giovanni Gentile, to sponsor a text series in which the coterie of talented young classicists he had gathered around himself at the Scuola could publish the Renaissance Latin texts they had edited. ${ }^{36}$ Once in America,

34 See MonfASANI, "The Renaissance and Renaissance Humanism in America Before and After Wallace K. Ferguson's The Renaissance in Historical Thought: An Historiographical Essay ", Rassegna Europea di Letteratura Italiana, 48 (2016), p. 71-90.

35 I am relying on a section of Kristeller's curriculum vitae in my possession that is a listing in twenty-two pages of « Lectures given in America » from 1939 to 1992.

36 Giovanni Gentile wrote a two page announcement entitled « Nuova collezione di testi umanistici a cura di Giovanni Gentitle e Paolo Oscar Kristeller » that was inserted as a sort of postface at the end of vol. II of Kristeller's 1937 Supplementum Ficinianum. In the announcement Gentile praised his collaborator as " un giovane dotto, tedesco d'origine ma diventato italiano per l'amore. » In the Reminiscences, p. 295-296, Kristeller explained: « Beginning in 1934, I found many interesting unpublished text that concerned not Ficino himself but either members of his circle or contemporaries [...] and I succeeded in persuading Gentile and Olschki that there should be a 
however, Kristeller could unleash in full his organizational impulses. He first became actively involved with the Committee on Renaissance Studies of the American Council of Learned Societies, and when the ACLS would no longer support the Renaissance committee, in 1954 he became one of the founding members of the Renaissance Society of America, and in 1957 its second president.$^{37}$ One of the projects he proposed to the Renaissance committee of the ACLS, a project he seems to have conceived of in 1943/1944 and of which he became its heart and soul for the next thirty years was the Catalogus Translationum et Commentariorum. Mediaeval and Renaissance Latin Translations and Commentaries, a vast cooperative enterprise that seeks to list and analyze every commentary on Latin classical and patristic texts since the end of antiquity and every translation of and commentary on Greek classical and patristic texts in the same period up to the year $1600 .^{38}$ His correspondence for the years $1945-1946$, when he was getting the project off the ground, as preserved in the Kristeller Papers at Columbia, is utterly monumental. He tried to interest in the project organizations such as the ACLS' Renaissance Committee, the Medieval Academy of America, and the American Philological Association, while at the same time recruiting a very broad group of scholars to participate and organizing meetings for those committed to the project to flesh out the details of the undertaking. ${ }^{39}$ In a report of 1951, he listed 239 scholars with whom he had been in correspondence concerning the Catalogus, in addition to fourteen other members of the editorial board with whom he was in frequent contact. ${ }^{40}$ Not until the early 1970s did he turn over the leadership of the Catalogus to his friend, F. Edward Cranz, who oversaw the production of volume III of the series (today the Catalogus has published its eleventh volume under the leadership of its fourth general editor, Greti Dinkova-Bruun). ${ }^{41}$

series of humanistic texts to be edited [...] the Scuola Normale would subsidize it [...] the involvement of the Scuola Normale was justified because with the encouragement of Gentile I persuaded many of my young friends in Pisa to undertake such texts, and at least half a dozen were assigned before I left Pisa ».

37 See KRISTELlER, Reminiscences, p. 404, 548-554, 606-611; and the delightful F. EDWARD CRANZ, « Fifty Years of the New England Renaissance Conference », Renaissance Quarterly, 42 (1989), p. 749-759.

38 See fn. 41 below.

39 See the next fn.

40 The address given for communications was Kristeller's office in Casa Italiana, Columbia University (1161 Amsterdam Ave., New York). See «Latin Translations and Commentaries, Medieval and Renaissance » by P. S. [sic] KRISTELler, in S. HARRISON THOMSON, Progress of Medieval and Renaissance Studies in the United States and Canada. Bulletin no. 21 (1951), University of Colorado Boulder, Boulder, p. 76-84. A second and third annual report by Kristeller was published in ibid., Bulletin no. 22 (1953), p. 52-55; and a fourth, fifth, and sixth report in ibid., Bulletin no. 24 (1957), p. 34-35.

41 In the Reminiscences, p. 550-558, Kristeller dates the start of the project as a cooperative venture to a meeting of interested scholars in April 1945 at the New Yorker Hotel hosted by Leicester 
At the same time that he was launching the Catalogus, Kristeller also was a prime mover in establishing Columbia University's Renaissance Seminar, which he served as secretary for many years and since 1945 has been a well-known venue for Renaissance scholars from everywhere to come and deliver papers on their research. ${ }^{42}$ Last, but not least, in these years Kristeller was actively seeking support for his Iter Italicum, though it must be said that until the 1970s, a project that should have been the work of an équipe of scholars, remained in fact a oneman show, the product, as Kristeller put it in the preface of volume III, of his left and right arms. ${ }^{43}$

The last, and fifth, of the changes America brought about in Kristeller was that it made him think very seriously about the history of philosophy and of history in general. In his Reminiscences Kristeller remarks that had he stayed in Germany, he would have pursued a philosophical synthesis combining Neo-Kantianism, Neoplatonism, and existentialism, but that he found in America a philosophical climate so uncongenial to his outlook that it discouraged him from continuing along this path. ${ }^{44}$ Instead, he concentrated on another theoretical interest, history and the history of philosophy. ${ }^{45}$ Already in Germany, first with Heinrich Rickert in Heidelberg, then in Marburg with Martin Heidegger he had studied the philosophy of history. So not surprisingly his first theoretical writings in America were on history, beginning with an article in 1943 on the method of history,

Bradner, as the secretary of the Renaissance Committee of the American Council of Learned Societies. Vol. 1 appeared in 1960: Catalogus Translationum et Commentariorum: Medieval and Renaissance Latin Translations and Commentaries. Annotated Lists and Guides, Washington, DC, Catholic University of America, under the aegis of the Union Académique Internationale, to which Kristeller wrote annual reports from 1953 to 1969 (see GILBHARD, Bibliographia, no. 163, for a list of the reports published in the annual Compte rendu of the Union). Kristeller's preface of 21 April 1958 to the first volume has been reprinted at the start of every volume ever since. The last volume Kristeller edited was vol. 2, which appeared in 1971. Kristeller's correspondence in connection with the Catalogus occupy three boxes of his papers: POKP, Boxes 96-98; with substantial other related correspondence in Boxes 100 and 101.

42 See Reminiscences, p. 532-539; and the seminar's website <http://universityseminars.columbia.edu /seminars/the-renaissance/>. A whole box of the Kristeller Papers is given over to his correspondence concerning the seminar: POKP, Box 113.

43 KRISTELLER, Iter Italicum, III, p. XIX: « As my late friend Robert Branner put it, my équipe consisted mainly of my right and left arms ».

44 See KRISTELLER, Reminiscences, p. 951-952: «If I had remained in Germany I might have pusued a philosophical synthesis that combined elements of Neo-Kantianism of the realist kind, NeoPlatobnism and existentialism [...] My emigration first to Italy and then to America discouraged any further work along these lines, since I encountered a philosophical climate, especially in America, that was quite uncongenial to my philosophical outlook». He expressed the same sentiment in almost the same words in his "Philosophical Testament»; see MonfasAnI, « Kristeller and Philosophy », p. 408-409, paragraphs 19 and 21.

45 See PaUl OsKar Kristeller, "Historical Scholarship and Philosophical Thought », Minerva, 18 (1980), p. 313-323, where he says at the start, p. 313: « The centre of my interest and of my work has always been the history of philosophy ». 
where, echoing Rickert to an extent, he distinguished the methods and aims of history from that of science and the social sciences, followed by another article in 1946 on "The Philosophical Significance of the History of Thought ». ${ }^{46}$ Kristeller would go on to write five more significant essays on history and the history of philosophy, the last in 1991, and one of which resulted in his having for the first time in his life an article rejected by a journal. ${ }^{47}$ This problematic piece contained sarcastic remarks concerning linguistic analysis that the editor feared would offend the journal's subscribers. ${ }^{48}$ But Kristeller's most personal and deepest thought about history came not in any of his articles on the subject, but in a talk he gave in 1961 on Renaissance philosophy and medieval traditions. I have quoted it before in other venues, but it is worth repeating here:

[I]f I may be allowed to conclude with a personal confession, I believe that nothing that once was can be completely undone. Even if destroyed in the material world and forgotten by men, it remains and will remain alive in the memory of an infinite being for which the past as well as the future is always present, and that is thus the greatest, the only true historian, and the keeper of the eternal tradition of which even our best human traditions, to use a Platonist phrase, are but shadows and images. ${ }^{49}$

I noticed some years ago that Kristeller's thoughts on God, history, and time seem to echo some positions of Alfred North Whitehead..$^{50}$ When Kristeller first came to America, he met Whitehead, then a very old man, at Harvard..$^{51}$ Significantly, in

46 See PAUl OsKar KRISTELleR, « Some Remarks on the Method of History », The Journal of Philosophy, 40 (1943), p. 225-245, written with Lincoln Reis (but see MonfASANI, "Kristeller and Philosophy », p. 398, fn. 64); and ID., "The Philosophical Significance of the History of Thought ", Journal of the History of Ideas, 7 (1946), p. 360-366 (reprinted multiple times; see GILBHARD, Bibliographia, no. 86).

47 See Monfasani, Kristeller and Philosophy, p. 397-405.

48 KRISTELLER, Reminiscences, p. 691-692: « Then I published a methodological article on the history of philosophy and the history of ideas in the Journal of the History of Philosophy [GILBHARD, Bibliographia, no. 283], in 1964. It has a peculiar history, because the article was commissioned by an Australian scholar, [John] Passmore [then at Canberra], who wanted to publish it in a periodical, History and Theory. This article of mine contained some sarcastic remarks about linguistic analysis, which is of course dominant in the English-speaking countries, and he felt that he could not afford to offer that to his audience, so it is the first instance when an article of mine was commissioned and then rejected ».

49 PAul OsKar Kristeller, Renaissance Philosophy and the Medieval Tradition, Archabbey Press, Latrobe, PA, 1966 (Wimmer Lecture, 15), p. 81-82 (see Gilbhard, Bibliographia, no. 321 for reprints and translations). See MonfasanI, « Kristeller and Philosophy », p. 404; and ID., «Italy in the Career », p. 20-21.

50 MonfaSANI, «Italy in the Career », p. 19-20; and ID., « Kristeller and Philosophy », p. 404-405, fn. 93.

51 KRISTELLER, Reminiscences, p. 373: « [visiting Harvard soon after arrival in America] I do remember also old Whitehead (Alfred North Whitehead) was alive, and the nice secretary of the Philosophy Department arranged for me to have a visit with Whitehead. He was already a very old man, tired, 
his Reminiscences, Kristeller also mentions that he later read Whitehead and was influenced by him..$^{52}$ So even in his mature thinking about history, coming to America was pivotal for Kristeller.

Kristeller adapted himself to America, but his early career was not easy and left him in a position of relative insecurity until he achieved fame with the publication of his Martin Classical Lectures at Oberlin College in 1954. The lectures were published by Harvard University Press in 1955 and reprinted in the extraordinarily successful paperback, Renaissance Thought: The Classic, Scholastic, and Humanist Strains, put out by Harper Torchbooks in $1961 .{ }^{53}$ In 1956 Columbia University promoted him to full professor, and in that same year appeared the first of the four volumes of his massive Studies in Renaissance Thought and Letters, containing twenty-five of the more than forty-eight articles he had published up to that time.$^{54}$ So by the mid-1950s, after fifteen years in America, Kristeller had arrived as one of the most preeminent scholars in America, a fact confirmed by his election in 1955 as a Fellow of the American Academy of Arts and Sciences. ${ }^{55}$

Why Kristeller had achieved this exalted status can be explained rather succinctly. By the mid-1950s he had published four significant books, one on Plotinus, two on Marsilio Ficino, and one consisting of some of his most important articles published up to that date; he had revolutionized whole sectors of scholarship, from the interpretation of Renaissance humanism and Italian scholasticism, to the understanding of Marsilio Ficino, to the study of manuscripts starting with his two articles on manuscript catalogues and unprinted inventories that were first brought together in a book in 1960, which quickly went out of print, ${ }^{56}$ to, finally, brilliant ground-breaking research on a

white haired, and he listened to me for a while and was very friendly and encouraging, and I remember his saying, 'I have a hunch that you will become a professor in this country' ».

52 Ibid.: "I have subsequently become interested in his work, and have great respect for it ". Interesting is the connection to Whitehead made by another student of Martin Heidegger, Elisabeth Feist Hirsch, «Remembrances of Martin Heidegger in Marburg », Philosophy Today, Summer 1979, p. 160-169, that I quote from EAD., Selected Writings, Franklin Press, Germantown, MD, 1993, p. 336-345, at p. 342: «I do not know how thoroughly Heidegger was acquainted with the philosophy of Whitehead's philosophy of process but he thought that Whitehead's philosophy, which involves ever new creations or 'occasions' had an affinity to his own thinking ».

53 For this bibliographical history see GILBHARD, Bibliography, nos. 172 and 242.

54 See GilBHARD, Bibliographia, no. 187, for an analysis of the volume. Vol. 2 appeared in 1985; vol. 3 in 1993; and vol. 4 in 1996.

55 A comment on Kristeller's achievement made not long after, in 1958-1963, by Hans Wallach to Elisabeth Feist Hirsch, like Wallach a German refugee and a long-time friend of Kristeller is poignant: «I only recently realized how important P.O. has become. Martin Ostwald here said flatly: Kristeller is a great man. He deserves to be, for he has devoted his life in a single-minded way to very hard work » (TEDESCHI, « Kristeller and Feist Hirsch », 252; see also p. 248-249).

56 This work, destined to become a scholarly classic, first appeared as an article in Traditio, 6, in 1948, followed by a second edition as an article in Traditio, 9, in 1953, and finally in its third 
variety of subjects, such as Renaissance Hermeticism, Early Modern atheism, and the origin of the modern system of the arts. ${ }^{57}$ And all the while people knew that he was preparing an epochal publication on Renaissance manuscripts, the Iter Italicum, the first volume of which appeared in 1963. But what needs to be asked and what will constitute the last part of this paper is how did Kristeller so quickly and successfully integrate himself into the American academic and, in general, intellectual scene.

The first answer is obvious, but crucial, namely, his swift mastery of English. He had studied English privately already when he was a schoolboy in Germany. ${ }^{58}$ But even more importantly, he was linguistically gifted. Unlike many émigrés, Kristeller came to speak English without an accent. He had his difficulties at the start. In the Plotinus seminar at Yale in the spring of 1939, he always wrote out an outline in English of what he would say in the seminar and then went over it with Roland Bainton, his sponsor at Yale. ${ }^{59} \mathrm{I}$ recall him in a seminar at Columbia in 1965-1966 still complaining about his being forced in 1939 to translate into English for publication a newly discovered Italian poem of Michelangelo when his English was still a work in progress. ${ }^{60}$ Anyone reading his earliest American talks and publications will discover occasional errors of grammar or idiom. But amazingly quickly he became a master of spoken and written English.$^{61}$ Indeed, in many years of hearing him, I encountered only one strange quirk: he would

edition as a book: Latin Manuscript Books Before 1600: A List of the Printed Catalogues and Unpublished Inventories of Extant Collections, Fordham University Press, New York 1960. Reprinted in 1965, it was thoroughly revised and expanded in a fourth edition by SIGRID KRÄMER in 1993 for the Bayerische Akademie der Wissenschaften, München. See GILBHARD, Bibliographia, nos. 100, 158, 227, 300, 594, 673.

57 On Kristeller's article on the modern system of the arts see MonfASANI, «Kristeller and Philosophy », p. 395-397. For Kristeller's ground-breaking articles on Renaissance Hermeticism see GilbHARD, Bibliographia, nos. 14 (in 1938), 38 (in 1941), and 228 (in 1960). The article on the myth of Renaissance atheism first appeared in Spanish in 1953 before being translated into English and French; see ibid., no. 160.

58 Kristeller's mother was fluent in English; see KRISTELLER, Reminiscences, p. 7; for his private tutors in English and French see ibid., p. 48. He also had eight years of French in school and one year of English (ibid., p. 48-49).

59 Ibid., p. 367: «I gave a seminar on Plotinus and I had to prepare it, and I wrote down my English outline, and I think Bainton went over it so that my English would as least be correct if not fluent ».

60 See Charles De Tolnay, « Michelangelo Studies », The Art Bulletin, 22/3 (Sept. 1940), p. 127-137, at p. 127: "The following transcription, with word-separations, accents, and punctuation in accordance with modern usage, has been made by Dr. Paul Oskar Kristeller of Columbia University, who has also been kind enough to provide the English translation ».

61 This was so much the case that late in life he found writing in English easier than doing so in German; see his letter of 7 May 1994 in response to a letter written in German by W. Cameron McEwen (POKP, Box 35, folder 6): «I have your interesting letters of May 3 (in German) and May 4 (in English). You will allow me to reply in English. My English may not be perfect, but after 55 years in this country, it is easier for me, especially when I discuss professional subjects ». 
invariably pronounce 'simple' as 'sample', probably under the influence of French pronunciation, a language in which he was fluent from youth.

The second reason for Kristeller's quick integration into American academia would seem to contradict the first, namely, the network of German acquaintances whom he found waiting for him upon arrival in America. ${ }^{62}$ We have already seen how Hermann Weigand of Yale (American born of German parents) was waiting for him at the dock in New York in 1939. Kristeller would initially stay in Weigand's house while teaching his seminar on Plotinus at Yale. Others at Yale providing material as well as moral support were the expert on ancient Assyria, Albrecht Goetze, the distinguished historian Hajo Holborn, the musicologist Leo Strade, the then young historian Theodore Mommsen, Jr., and yet another young refugee scholar, Elizabeth Feist, who would become a very dear friend of Kristeller's. ${ }^{63}$ At the University of Chicago was his old teacher Werner Jaeger. Kristeller was seemingly promised a position at Chicago, but the offer evaporated when Jaeger transferred to Harvard in the fall of $1939 .{ }^{64}$ The Kristeller Papers at Columbia contain extensive correspondence with other German refugee scholars from these early years, such as Friedrich Solmsen, initially at Mount Olivet College in Michigan and then Cornell University, ${ }^{65}$ Hans Baron in New York, Erwin Panofsky at Princeton, Ludwig Edelstein at Johns Hopkins in Baltimore, Leo Spitzer also at Johns Hopkins, Herbert Dieckmann at Washington University in St. Louis, Karl Löwith after he arrived at Hartford Theological Seminary from Japan in 1941, and Hannah Arendt after she too arrived in America in 1941, all of whom corresponded with Kristeller at least initially almost exclusively in German.

Nor did Kristeller's dealings with other German refugees reflect only scholarly interests and/or his desire to integrate himself in America. Hans Baron, who became famous in the 1950s, is a case in point. Hard of hearing and overly sensitive to perceived slights that led to quarrels with colleagues, Baron had lost

62 See Kristeller's humorous comment in Reminiscences, p. 375: « And when I arrived I joked. I said that when people came to this country they had to have either a bankbook or an address book. I didn't have a bankbook, but I had an address book ».

63 See Tedeschi, Correspondence of Roland H. Bainton, p. 97-99, 255-256; and ID., «Paul Oskar Kristeller and Elisabeth Feist Hirsh: A Lifetime Connection » in MonfaSAnI, Kristeller Reconsidered, p. 233-225.

64 Jaeger told Kristeller in letters of 12 and 29 March 1939 of talks with Dean Richard McKeon about the possibility of a fellowship at the University of Chicago (POKP, Box 27, folder 3). Kristeller speaks of this possibility in Reminiscences, p. 331: «I personally wrote to my teacher Werner Jaeger, who was at that time at the University of Chicago, and he practically arranged for me to come to Chicago with a fellowship. Then he left for Harvard, and as soon as he left the people in Chicago forgot about it, and nothing happened »; and p. 383: « Then I went to Chicago and I met two important people with whom I had had correspondence. One was the philosopher Richard McKeon, a great authority on medieval philosophy who had been involved by Jaeger in an attempt to get me to Chicago on a fellowship, something that fell apart after Jaeger left Chicago ».

65 This extensive correspondence is found in POKP, Box 53, folder 17. 
his position at Queens College in New York in the early 1940 s. ${ }^{66}$ I recently came across a letter of Kristeller's to James Hutton at Cornell in which Kristeller asked Hutton if he could find something for Baron at Cornell. ${ }^{67}$ There is even an earlier letter of E. A. Lowe at the Institute for Advanced Study in Princeton, asking Kristeller what he thought of Baron, who had applied for a fellowship. ${ }^{68}$ Since Baron did become a member of the Institute, Kristeller's response, we can safely assume, was highly supportive.

Finally, we need to look at a neglected aspect of Kristeller's first years in America, namely, the massive number of reviews he wrote, especially in The Journal of Philosophy, which had its offices at Columbia University and which made Kristeller a book editor, doubtlessly on the recommendation of John Herman Randall, in 1940. ${ }^{69}$ Between 1939 and 1954 Kristeller published seventy-nine book reviews, somewhat more than five a year, in various journals on a wide range of books, mainly in Renaissance studies, but also in other areas, especially in ancient philosophy. ${ }^{70}$ Indeed, between the time of his German dissertation on Plotinus in 1928 and his article on the Ideas in Middle Platonism, again in German, more than sixty years later, in $1989,{ }^{71}$ his only publications on ancient philosophy were the reviews he wrote in English as he exploited his position as book editor to impress upon his American audience his expertise in the history of ancient philosophy. But he also wrote reviews of books on the Inquisition in medieval Narbonne, on Paraclesus, on St. Thomas More, on Giambattista Vico, on Renaissance art, on English drama, and on medieval literature, specifically, on Ernest Robert Curtius' Europaische Literatur und Lateinisches Mittelalter in 1950. It is unfortunate that Kristeller did not include any of these reviews in the four volume of his Studies in Renaissance Thought and Literature since many are immensely learned, offering erudite corrections and fresh manuscript information. Interestingly enough, in reviewing one book, Eugenio Garin's Der italienische Humanismus of 1947, a book with an interpretation diametrically opposed to his, Kristeller came close to writing a non-review, merely reporting the contents of the book and

66 See KAY SCHILLER, Gelehrte Gegenwelten: Über humanistische Leitbilder im 20. Jahrhundert, Fischer Taschenbuch Verlag, Frankfurt a. M. 2000, p. 99-173; GERHARD A. RITTER, German Refugee Historians and Friedrich Meinecke. Letters and Documents, 1910-1977, trans. ALEX SKINNER, Brill, Leiden - Boston 2010 (Studies in Central European histories, 49), p. 56-61, 286-319; and MoNFASANI, « Renaissance and Renaissance Humanism », p. 76-81, 88-89.

67 POKP, Box 26, folder 6, for Kristeller's letter of 19 October 1948 to Hutton.

68 POK, Box 34, folder 8, for Lowe's letter of 13 March 1946 to Kristeller.

69 He first appeared as one of the book editors in the vol. 37, no. 4 (July 4, 1940) issue of the Journal and ceased to be listed as such in vol. 48, no. 26 (Dec. 20, 1951), when the position of book editor itself ceased to be listed in the Journal's masthead.

70 See GILBHARD, Bibliographia, nos. 25, 27-36, 41-47, 52-57, 61-66, 70-72, 77-83, 87-92, 96-98, $102-$ $105,109-117,128-132,140-146,150-152,168-169$.

71 He anticipated the argument of his 1989 article in a review of Georg Luck's Der Akademiker Antiochos that he wrote in 1959 in The Journal of Philosophy, 56, p. 425-27, at p. 426. 
commenting on the ambiguity of the term humanism and the need not to take rhetorical statements as genuine expressions of an author's views. ${ }^{72}$ Kristeller was obviously determined to avoid any criticism of the scholar who had been a friendly acquaintance in Italy and who would go to be his greatest rival in the debate over Renaissance humanism. Not that Kristeller was normally shy in voicing criticism. In the case of one book, he remarked that its defects were « likely to make the book unsatisfactory to the scholar and dangerous for the general reader ». ${ }^{73}$ And concerning another, he explained: « This whole section is needlessly repetitious and filled with verbatim quotations from more or less modern sources that are of dubious value, selected without judgment, and cited without care ${ }^{74}{ }^{74}$ As much as any of his other publications, the English language reviews revealed how caustically witty Kristeller could be

Kristeller was not ubiquitous in his first fifteen years in America, though he may have seemed so between his reviews, itinerant lecturing, continuous organizational meetings and petitions, and, of course, his stupendous outpouring of learned articles. I have already given a great deal of evidence of Kristeller's integration into American academia at the highest levels by the mid-1950s. But recently I came across a most poignant, but unpublished testimony that can fittingly end this talk. Wallace K. Ferguson had literally written the book on the interpretations of the Renaissance to the mid-twentieth century, i.e., The Renaissance in Historical Thought. On February 10, 1957, Ferguson wrote Kristeller that he had just read Kristeller's Martin Classical Lectures in the first edition put out by Harvard University Press in 1955. One has to keep in mind that by that date Ferguson had read Hans Baron's and Eugenio Garin's works on Renaissance humanism. Indeed, he had already participated in a symposium on the Baron thesis at a recent meeting of the American Historical Association. ${ }^{75}$ So with full knowledge of the various interpretations, he wrote Kristeller:

I do not see how anyone could have got more information and more sane and discriminating interpretation into four lectures. It all makes sense and that is more than can be said for a great deal of writing about humanism. It is also

72 Kristeller gave a brief notice in The Journal of Philosophy, 47 (1950), p. 222-223; he wrote the review for The Romanic Review, 41 (1950), p. 218-219. See StÉPHANE Toussaint, "Kristeller, Garin e l'Umanesimo. Appunti Ritrovati ", in Stefano Caroti, Vittoria Perrone Compagni (eds.), Nuovi maestri e antichi testi: Umanesimo alle origini del pensiero moderno. Atti del Convegno internazionale di studi in onore di Cesare, Leo S. Olschki, Firenze 2002 (Ingenium, 17), p. 157-166, for a discussion of Kristeller's notes in Garin's book preserved in the Fondo Kristeller of the Scuola Normale Superiore in Pisa.

73 Review of Charles Norris Cochrane, Christianity and Classical Culture in The Journal of Philosophy, 41 (1944), p. 577.

74 Review of Giovanni Di Napoli, Tommaso Campanella filosofo della restaurazione cattolica, in The Philosophical Review, 59 (1950), p. 251.

75 See MonfaSAnI, « Renaissance and Renaissance Humanism », p. 76-77. 
beautifully written. The last sentence on page 89 is alone worth the price of the book. ${ }^{76}$

That last sentence on p. 89 is, in fact, a typical dictum of Kristeller, one that he voiced more than once in conversation and in print. And so, giving Kristeller the last word, I quote it as another example of his wit:

Originality is greatly to be admired, but it is a gift of nature or providence; it cannot be taught, and I doubt that it is harmed by knowledge or increased by ignorance. $^{77}$

76 A letter of Ferguson to Kristeller of 10 February 1957 in POKP, Box 18, folder 6.

77 KrIsteller, Classics and Renaissance Thought, p. 89 (= ID., Renaissance Thought and Its Sources, p. 80). The quoted passage occurs on the last page or so of the last of the Martin Classical Lectures, «Paganism and Christianity ». 


\section{Appendix 1}

\section{A Notarized Memorandum concerning Kristeller's Parents in 1942}

The memorandum is to be found in POKP, Box 65, folder 8 . I have no information concerning the author, Ella Dekuzcynski. Moreover, since at the time Germany and the United States had already been at war with each other for five months, one would like to know the circumstances that allowed her to be in Berlin that spring and then leave for and arrive in New York shortly after. She may have been in Berlin in an attempt to rescue relatives. Both the Gedenkbuck Berlins, p. 242, and Gedenkbuch: Opfer der Verfolgung der Juden, p. 253, record the death of Herbert and Irma Dekuzcynski (née Hauser) at Auschwitz without a specific date, and of a Rosa Dekuzynski in Minsk, whose death Theresienstädter Gedenkbuch, p. 41, dates as 23 July 1942 in Treblinka.

The formal nature of the memorandum suggests it was meant to help justify Kristeller's claim for a refund of the funds he had spent to acquire the Cuban visa for his parents.

Ella Dekuzcynski

602 West 137th Street

Apt. 53

New York, N.Y.

June 8,1942

To whom it may concern:

This is to certify that, on May 15th, 1942, the day before I left Berlin for New York, I met Mr. Heinrich KRISTELLER, father of Dr. Paul Oskar Kristeller of Columbia University, resident of New York (611 West 114th Street, Apt. 6 A).

Mr. Heinrich Kristeller told me that the Cuba visa which his son had applied for on behalf of his parents had been rejected.

\section{[signature] Ella Dekuzcynski}

[typed] Ella Dekuzcynski

[handwritten]

State of NY

County of NY

Sworn to before me this 9th day of June 1942

Raphael Pivick

[underneath: Notary Republic Stamp of Raphael Pivick] 